\title{
Geochemical fingerprints of early diagenesis in Pleistocene shallow- water marine carbonates
}

\author{
ALLIYA A AKHTAR, ANNE-SOFIE C AHM, JACK
} MURPHY, ADAM MALOOF AND JOHN HIGGINS

Princeton University

Presenting Author: aakhtar@princeton.edu

Shallow-water carbonates represent an important and widely used archive of the history of the global carbon cycle and chemical composition of seawater. However, these sediments are likely to have some of the most complicated early diagenetic histories due to the potential for alteration by both marine and meteoric fluids. Here we present a full suite of major element stable isotope $\left(\delta^{13} \mathrm{C}, \delta^{18} \mathrm{O}, \delta^{44 / 40} \mathrm{Ca}, \delta^{26} \mathrm{Mg}\right)$ and selected trace element (e.g. $\mathrm{Sr} / \mathrm{Ca}, \mathrm{Mg} / \mathrm{Ca}$ ) data from Pleistocene sediments from the Great Barrier Reef (IODP Expedition 325), as well as Holocene surface sediments from the Bahamas (Triple Goose Creek, Andros Island) to identify geochemical fingerprints associated with early marine and meteoric diagenesis. Sediments from both sites exhibit co-variation in $\delta^{13} \mathrm{C}$ and $\delta^{18} \mathrm{O}$ values and depletion in trace elements but distinct geochemical trends in $\delta^{26} \mathrm{Mg}$ and $\delta^{44 / 40} \mathrm{Ca}$ values that reflect differences between diagenetic alteration by marine and meteoric fluids. In particular, while marine diagenesis results in lower $\mathrm{Sr} / \mathrm{Ca}$ ratios, higher $\delta^{44 / 40} \mathrm{Ca}$ values, and $\delta^{26} \mathrm{Mg}$ values that are similar to the initial bulk sediment, meteoric diagenesis leads to lower $\mathrm{Sr} / \mathrm{Ca}$ ratios, lower $\delta^{44 / 40} \mathrm{Ca}$ values, and distinctly lower $\delta^{26} \mathrm{Mg}$ values. Using a numerical model of diagenesis, we show how the dissolution and re-precipitation of carbonate minerals during meteoric diagenesis results in a progressive lowering of bulk sediment $\delta^{44 / 40} \mathrm{Ca}$ and $\delta^{26} \mathrm{Mg}$ values and discuss how paired metal isotopes may serve as a robust indicator of meteoric alteration in ancient shallowwater marine carbonate sediments. 